\title{
Detection of Fc receptor genes from Staphylococcus aureus and streptococci by polymerase chain reaction
}

\author{
S. YAMADA, J. YAMAGISHI* and A. MATSUMOTO \\ Department of Microbiology, Kawasaki Medical School, Kurashiki, Okayama 701-01 and *Discovery Research \\ Laboratories II, Dainippon Pharmaceutical Co. Ltd, Suita, Oasaka 564, Japan
}

\begin{abstract}
A method based upon the polymerase chain reaction (PCR) for detecting genes encoding the Fe receptors of Staphylococcus aureus and streptococci is described. Primers were designed from the nucleotide sequences of the five $F c$ receptor genes encoding protein $A$, protein G, protein $\mathbf{H}$, FcRA and protein $V$. Amplification products corresponding in size to the protein $A$ and protein $G$ genes were detected in $S$. aureus strain Cowan 1 and Streptococcus pyogenes strain G148, respectively, as expected. Str. pyogenes strain AR1 was shown to possess the type $\mathrm{H}$ receptor gene. Two clinical isolates of Str. pyogenes, strains IP-28 and ES-21L, were shown to possess genes for Fc receptor types FcRA and protein G, respectively. The identification of all these products was confirmed by restriction endonuclease analysis. Amplification of protein $H$ genes from two other clinical isolates of streptococci, MS-4 and MS-38, yielded a product larger than expected and with a different restriction fragment pattern to strain AR1, indicating a new type of Fe receptor gene. This PCR method provides a DNA-based method for the determination of $F c$ receptor type in $S$. aureus and streptococci.
\end{abstract}

\section{Introduction}

Bacterial cell-surface receptors for the $\mathrm{Fc}$ portion of host immunoglobulin $\mathrm{G}$ ( $\mathrm{IgG}$ ) have been shown to contribute to virulence [1]. The $\mathrm{Fc}$ receptors of Staphylococcus aureus and some streptococci have been well documented as immunoglobulin-binding proteins $[1,2]$. The $\mathrm{Fc}$ receptor of $S$. aureus was designated protein A [3] and that of some Lancefield group $C$ and $G$ streptococci as protein $G[4,5]$. Some strains of group A streptococci also produce an $\mathrm{Fc}$ receptor called FcRA [6,7]. These Fc receptors were differentiated and classified on the basis of their binding patterns with the IgG of different mammalian species [2]; this method is still used to determine Fc receptor type.

Four different patterns of receptor distribution on the surface of gram-positive cocci, including $S$. aureus and streptococci, have been identified [8]. A further unique pattern of $\mathrm{Fc}$ receptor distribution has been described on the surface of two streptococcal strains

Received 5 Jan. 1996; revised version accepted 25 April 1996.

Corresponding author: Dr S. Yamada.
(MS-4 and MS-38), isolated from a single patient [8]. To investigate the genetic basis of the differences in receptor distribution, a method of determining $\mathrm{Fc}$ receptor type, and variation within these, is required. The present study aimed to establish a polymerase chain reaction (PCR)-based method to determine $\mathrm{Fc}$ receptor type and to use this method to characterise the $\mathrm{Fc}$ receptors of strains MS-4 and MS-38.

\section{Materials and methods}

\section{Bacterial strains and culture conditions}

Seven strains were examined in the present study. $S$. aureus strain Cowan I was supplied by Dr Y. Arai (Saitama Medical School, Saitama, Japan) and Streptococcus pyogenes strain AR1 and Streptococcus sp. strain G148 (Lancefield group G) were supplied by Dr Y. Minamishima (Miyazaki Medical College, Miyazaki, Japan). The Cowan I strain and the G148 strain produce protein A [3] and protein G [4], respectively. No control strains for proteins FcRA, $\mathrm{H}$ or $\mathrm{V}$ were available. The AR1 strain is a strong producer of $\mathrm{Fc}$ receptors [9], but these have not been typed. Four clinical isolates of streptococci, IP-28, ES-21L, MS-4 and MS-38, which had been confirmed previously to be 
Fc receptor positive by immuno-electron microscopy [8] but not typed, were also used. Strain MS-38 was isolated 4 days after the isolation of strain MS-4 from the same patient. The bacteria were cultured for $17 \mathrm{~h}$ at $37^{\circ} \mathrm{C}$ in $10 \mathrm{ml}$ of Trypto-Soya Broth (TSB; Nissui Pharmaceutical Co., Tokyo, Japan) and washed twice with Dulbecco's phosphate-buffered saline (PBS) before extraction of chromosomal DNA.

\section{Extraction of chromosomal DNA}

Extraction of chromosomal DNA from each strain was accomplished with a minor modification of the protocol described by Hudson and Curtiss [10]. Briefly, for streptococci, pelleted, washed cells were suspended in $1 \mathrm{ml}$ of TE buffer $(10 \mathrm{mM}$ Tris- $\mathrm{HCl}, \mathrm{pH} 7.5,1 \mathrm{~mm}$ EDTA) containing mutanolysin (Sigma) $100 \mu \mathrm{g} / \mathrm{ml}$. Staphylococcal cells were suspended in the same buffer containing lyostaphin $100 \mu \mathrm{g} / \mathrm{ml}$. The cell suspension was incubated for $60 \mathrm{~min}$ at $37^{\circ} \mathrm{C}$, and then pronase $\mathrm{K}$ was added to $1 \mathrm{mg} / \mathrm{ml}$, followed by an additional incubation at $37^{\circ} \mathrm{C}$ for $60 \mathrm{~min}$. After lysis with SDS $1 \%$ $\mathrm{w} / \mathrm{v}$ for $30 \mathrm{~min}$ at $37^{\circ} \mathrm{C}$, the genomic DNA was extracted with phenol:chloroform:isoamyl alcohol $(25: 24: 1)$ and precipitated with ethanol.

\section{PCR amplification}

The sequences of the primers for amplification of the Fc receptor genes are shown in Table 1. These were selected from the nucleotide sequences of $\mathrm{Fc}$ receptor genes, previously reported [6,11-14], and synthesised with a Biosearch 8750 automated DNA synthesiser.
Target DNA was amplified with the Perkin-Elmer Cetus GeneAmp PCR Reagent Kit and the PCR system 9600 (Takara Shuzo Co. Ltd, Kyoto, Japan), in a total volume of $50 \mu \mathrm{l}$ containing reaction buffer, $0.2 \mathrm{mM}$ dNTP mixture, 40 pmols each primer, $0.5-1 \mu \mathrm{g}$ of template DNA and 5U of AmpliTaq DNA polymerase. The amplification conditions consisted of 30 cycles comprising: denaturation for $15 \mathrm{~s}$ at $94^{\circ} \mathrm{C}$, annealing for $1 \mathrm{~min}$ at $55^{\circ} \mathrm{C}$ and extension for $1 \mathrm{~min}$ at $72^{\circ} \mathrm{C}$. The PCR products were examined by electrophoresis on agarose gels $(1 \% \mathrm{w} / \mathrm{v}$ in TBE buffer) and the bands were detected by staining with ethidium bromide. A negative control, containing all reagents except DNA, was included in each experiment.

\section{Restriction endonuclease analysis of $P C R$ products}

Amplification products $(10 \mu \mathrm{l})$ were digested with at least two of the following restriction endonucleases: HinfI; Hae II; RsaI; HaeIII;HgiAI; Fnu4H;HincII and PvuII; (Table 1) according to the manufacturer's instructions. The expected sizes of restricted products are also shown in Table 1.

\section{Results}

\section{$P C R$ amplification}

All seven bacterial strains were tested with each of the five pairs of primers. The PCR results are shown in Fig. 1. PCR amplification with the protein A primer set (AF-1 and AR-1) yielded a product of $1.7 \mathrm{~kb}$ only for

Table 1. Sequences of PCR primers for the amplification of Fc receptor genes

\begin{tabular}{|c|c|c|c|c|}
\hline Gene & Primer & Sequence & $\begin{array}{c}\text { Size of } \\
\text { expected } \\
\text { products }(b p)\end{array}$ & $\begin{array}{l}\text { Restricted by } \\
\text { (fragment sizes } \\
\quad>200 \text { bp) }\end{array}$ \\
\hline $\begin{array}{l}\text { Protein A } \\
{[11]}\end{array}$ & $\begin{array}{l}\text { AF-1 } \\
\text { AR-1 }\end{array}$ & $\begin{array}{c}5^{\prime} \text {-CCTTTAAATTTAATTATAAATATAGA-3' } \\
\text { DraI } \\
5^{\prime} \text {-CCTTTAAAGATATCTATCGTTGTGTA-3' } \\
\text { DraI }\end{array}$ & 1704 & $\begin{array}{c}\text { HinfI }(995,352) \\
\text { Hae II }(857,438,409) \\
\text { RsaI }(1223,214)\end{array}$ \\
\hline $\begin{array}{l}\text { FcRA } \\
{[6]}\end{array}$ & $\begin{array}{l}\text { XF-1 } \\
\text { XR-1 }\end{array}$ & 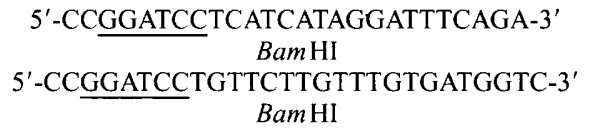 & 1342 & $\begin{array}{l}\text { Hinfl }(408,388,367) \\
\text { HincII }(471,449,422)\end{array}$ \\
\hline $\begin{array}{l}\text { Protein } \mathrm{H} \\
{[13]}\end{array}$ & $\begin{array}{l}\text { HF-1 } \\
\text { HR-1 }\end{array}$ & $\begin{array}{c}5^{\prime} \text {-CCGAATTCCAGCTGGAGTAGCAGCAGTT-3' } \\
\text { EcoRI } \\
\text { 5'-CCGGATCCGTATACGTTTCGGCTGAAAC-3' } \\
\text { Bam } \mathrm{HI}\end{array}$ & 1696 & $\begin{array}{c}\text { Hinfl }(1166,530) \\
\text { Hae III }(890,680) \\
\text { HgiAI }(731,596,213) \\
\text { Fnu4H }(775,335,279)\end{array}$ \\
\hline $\begin{array}{l}\text { Protein V } \\
{[14]}\end{array}$ & $\begin{array}{l}\text { VF-1 } \\
\text { VR-1 }\end{array}$ & $\begin{array}{c}5^{\prime} \text {-CCGAATTCTAATTTCGTTCGTTTATAAC-3' } \\
\text { EcoRI } \\
\text { 5'-CCGGATCCCTGTTTTATTGTCTATTCTC-3' } \\
\text { Bam } \mathrm{HI}\end{array}$ & 2075 & \\
\hline $\begin{array}{l}\text { Protein G } \\
{[12]}\end{array}$ & GF-1 & $\begin{array}{c}5^{\prime} \text {-CCTTTAAAAAGTCTTGTTTTCTTAAA-3' } \\
\text { DraI } \\
5^{\prime} \text {-CC } \underline{\text { TTTAAAAATACAAAAAAAGAGGAA-3' }} \\
\text { DraI }\end{array}$ & 2147 & $\begin{array}{c}\text { Hinfl }(1192,272,269,225) \\
\text { HincII }(918,394,335,290,210) \\
P v u \text { II }(1458,359)\end{array}$ \\
\hline
\end{tabular}

Underlined sequences represent restriction sites to enable cloning and sequencing of products. 
a

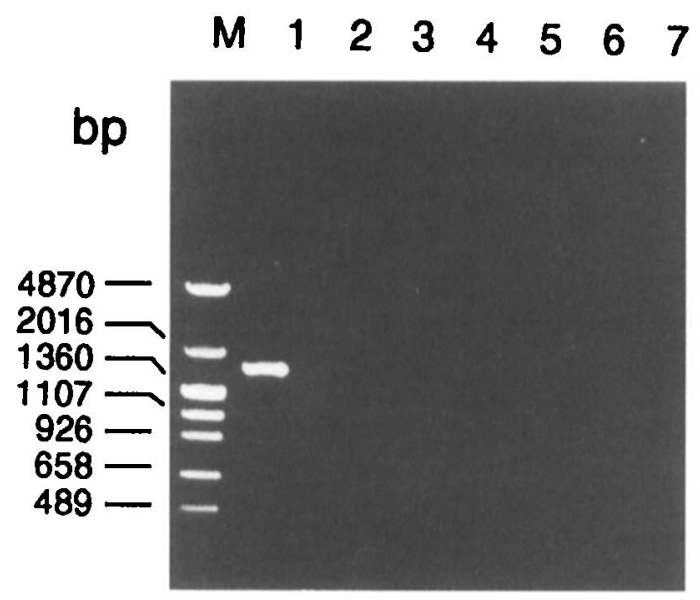

Protein A gene

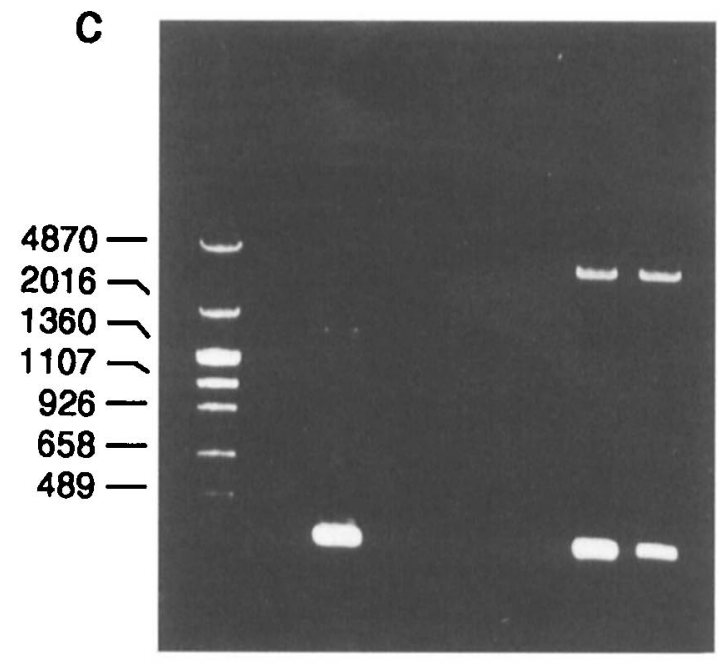

Protein $\mathrm{H}$ gene

e

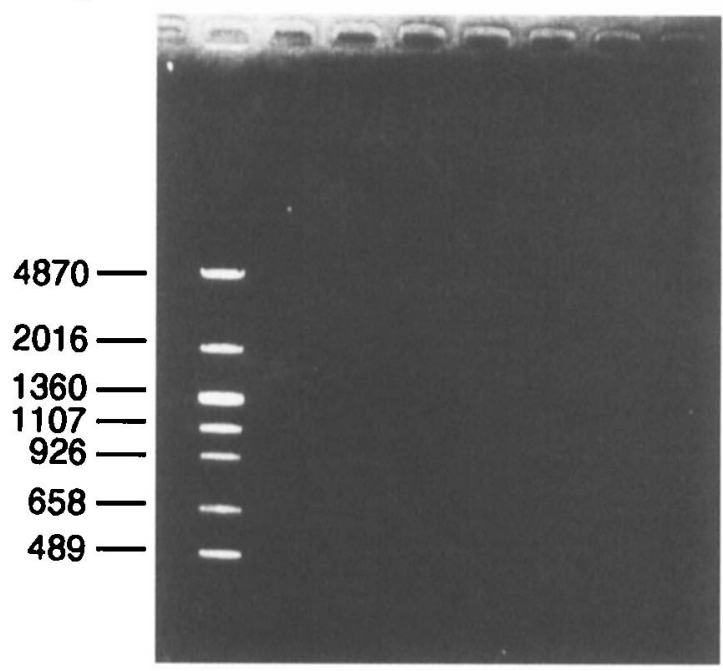

b
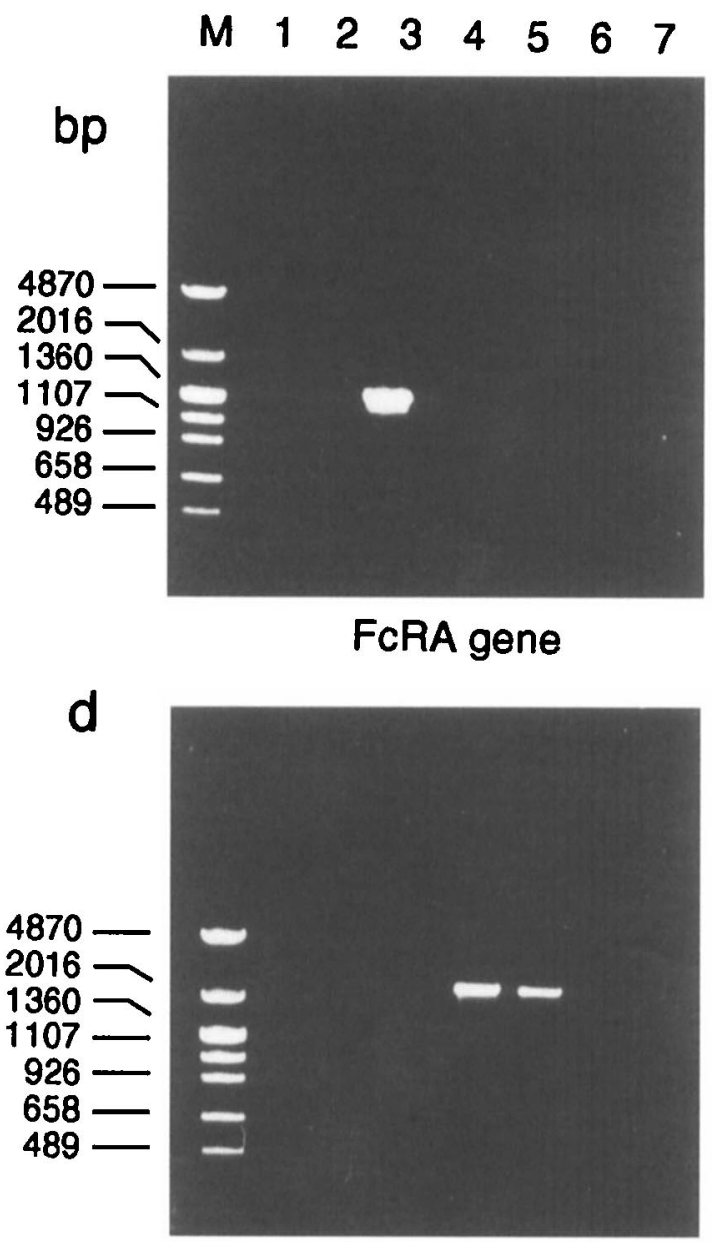

Protein G gene

\section{Protein V gene}

Fig. 1. Agarose gel electrophoresis of PCR products amplified with Fc receptor primers. The primer sets shown in Table 1 were used to amplify each $\mathrm{Fc}$ receptor gene as indicated: a, protein A gene; $\mathbf{b}$, FcRA gene; $\mathbf{c}$, protein $\mathrm{H}$ gene; d, protein $\mathrm{G}$ gene; e, protein V gene. Lanes: M, marker (pHY marker, Takara Shuzo); 1, S. aureus strain Cowan I; 2, streptococcal strain AR1; 3, streptococcal strain IP-28; 4, streptococcal strain G148; 5, streptococcal strain ES-21L; 6, streptococcal strain MS-4; 7, streptococcal strain MS-38. 
the Cowan I strain of S. aureus (Fig. 1a, lane 1). With the XF-1 and XR-1 primers, designed from the FcRA gene, only DNA from the streptococcal IP-28 strain was amplified, as a single product of $1.3 \mathrm{~kb}$, as expected for this gene (Fig. 1b, lane 3). When the HF-1 and HR-1 primers were used to amplify the protein $\mathrm{H}$ gene, two bands were detected in three strains (AR1, MS-4 and MS-38) (Fig. 1c). The smaller product $(c .300 \mathrm{bp})$ was common to these three strains. However, there was a clear difference between the larger bands of strain AR1 and the other two strains, MS-4 and MS-38. Although strain AR1 produced a faint band at $1.7 \mathrm{~kb}$ (Fig. 1c, lane 2), which corresponded to the full size of the protein $\mathrm{H}$ gene [13], the size of the PCR products from strains MS-4 and MS-38, $3.8 \mathrm{~kb}$, was unexpected (Fig. 1c, lanes 6 and 7). Amplification of the protein $G$ gene with primers GF-1 and GR-1 yielded products of $2.1 \mathrm{~kb}$, as expected for the full length of the protein $G$ gene [12], from strains G148 and ES-21L (Fig. 1d, lanes 4 and 5). No PCR product was detected when the VF-1 and VR1 primers, for the protein $\mathrm{V}$ gene [14], were used (Fig. 1e). No amplification of receptor genes other than those expected, was detected.

\section{Restriction endonuclease analysis of $P C R$ products}

With Hinfl, HaeII and RsaI, the product from the $S$. aureus Cowan I strain showed the cleavage pattern expected from the sequence of the protein $\mathrm{A}$ gene, determined by Uhlén et al. [11]. The pattern of fragments from the PCR products from the streptococcal strains AR1, IP-28, G148 and ES-21L showed the cleavage patterns expected from the sequences of the protein $\mathrm{H}$ gene [13], FcRA gene [6], protein $\mathrm{G}$ gene [12] and protein $\mathrm{G}$ gene [12], respectively. However, the cleavage patterns of strains MS-4 and MS-38, which were indistinguishable, differed from that expected from the sequence of the protein $\mathrm{H}$ gene [13].

\section{Discussion}

Five types of Fc receptors of gram-positive cocci have been completely cloned and sequenced. The protein A gene was sequenced by Uhlén et al. [11]. Olsson et al. [12] cloned the protein $G$ gene of the streptococcal strain G148, which is regarded as the standard protein $\mathrm{G}$ producing strain [4]. Fahnestock et al. [15] sequenced the $\mathrm{Fc}$ receptor from the streptococcal strain GX7809 and showed it to be a protein G variant. The $\mathrm{Fc}$ receptor genes, FcRA [6], protein $\mathrm{H}$ [13] and protein $\mathrm{V}$ [14], have been sequenced also. Based on the nucleotide sequences of these genes encoding $\mathrm{Fc}$ receptors, primers were designed for each gene and the results confirmed that these amplified products of appropriate sizes, for the protein A and protein $\mathrm{G}$ genes from $S$. aureus Cowan I strain and streptococcal strain G148, respectively. Strains AR1, IP-28 and ES-21L were shown to possess the protein $\mathrm{H}$ gene, FcRA gene and protein $\mathrm{G}$ gene, respectively. These results were confirmed by restriction endonuclease analysis of the products. The results also showed that the primers used in the PCR were specific for each of the four Fc receptor genes, protein $\mathrm{A}$, protein $\mathrm{G}$, protein $\mathrm{H}$ and FcRA, indicating that the PCR is suitable for the classification of $\mathrm{Fc}$ receptors. Furthermore, the present study showed that the Fc receptor genes of strains MS4 and MS- 38 were the same as each other but differed from those of the five known Fc receptors. Thus, a new $\mathrm{Fc}$ receptor gene was identified from Lancefield group A streptococci.

Amplification products obtained from the MS-4 and MS-38 strains were approximately twice the size expected for the protein $\mathrm{H}$ genes. However, the restricted fragment sizes of the products from these strains indicated that they were not duplications of the protein $\mathrm{H}$ gene [6]. These results suggest that strains MS-4 and MS-38 may have a receptor gene which is related to, but different from, the published protein $\mathrm{H}$ gene. The primers used in the present study enable products to be cloned or sequenced, or both, because they were designed to contain restriction sites (underlined sequence in the primers, Table 1). Sequencing of the products from strains MS-4 and MS-38 is being done to determine the nature of their $\mathrm{Fc}$ receptor genes.

Previously, the distribution of $\mathrm{Fc}$ receptors has been determined by the ferritin labelling method and four types of distribution on the surface of organisms have been described [8]. These morphological studies, together with the PCR and restriction endonuclease analysis described in the present study, will enable the relationship between the distribution of $\mathrm{Fc}$ receptors on the surface of organisms and the type of $\mathrm{Fc}$ receptor genes to be determined.

This study was supported by project grants (nos. 5-504 and 6-502) from Kawasaki Medical School.

\section{References}

1. Langone JJ. Protein A of Staphylococcus aureus and related immunoglobulin receptors produced by streptococci and pneumococci. Adv Immunol 1982; 32: 157-252.

2. Boyle MDP. Introduction to bacterial immunoglobulin-binding proteins. In: Boyle MDP (ed) Bacterial immunoglobulinbinding proteins, 2nd edn, vol 2: Applications in immunology. San Diego, Academic Press. 1990: 1-21.

3. Forsgren A, Sjöquist J. "Protein A" from $S$. aureus. I. Pseudoimmune reaction with human $\gamma$-globulin. $J$ Immunol 1966; 97: $822-827$.

4. Björck L, Kronvall G. Purification and some properties of streptococcal protein $\mathrm{G}$, a novel IgG-binding reagent. $J$ Immunol 1984; 133: 969-974.

5. Reis KJ, Ayoub EM, Boyle MDP. Streptococcal Fc receptors. I. Isolation and partial characterization of the receptor from a group C streptococcus. J Immunol 1984; 132: 3091-3097.

6. Heath DG, Cleary PP. Fc-receptor and M-protein genes of group A streptococci are products of gene duplication. Proc Natl Acad Sci USA 1989; 86: 4741-4745.

7. Cleary PP, Heath D. Type II immunoglobulin receptor and its 
gene. In: Boyle MDP (ed) Bacterial immunoglobulin-binding proteins, vol 1: Microbiology, chemistry and biology. San Diego, Academic Press. 1990: 83-99.

8. Yamada S, Matsumoto A, Uehira K, Suda T. Immunoelectron microscopy of $\mathrm{Fc}$ receptors on the surface of clinical isolates of streptococci. J Electron Microsc 1991; 40: 176-180

9. Kronvall G, Simmons A, Myhre EB, Jonsson S. Specific absorption of human serum albumin, immunoglobulin $A$, and immunoglobulin $\mathrm{G}$ with selected strains of group $\mathrm{A}$ and $\mathrm{G}$ streptococci. Infect Immun 1979; 25: 1-10.

10. Hudson MC, Curtiss R. Regulation of expression of Streptococcus mutans genes important to virulence. Infect Immun 1990; 58: 464-470.

11. Uhlén M, Guss B, Nilsson B, Gatenbeck S, Philipson L, Lindberg M. Complete sequence of the staphylococcal gene encoding protein A gene evolved through multiple duplications. J Biol Chem 1984; 259: 1695-1702.

12. Olsson A, Eliasson M, Guss B et al. Structure and evolution of the repetitive gene encoding streptococcal protein G. Eur $J$ Biochem 1987; 168: 319-324.

13. Gomi H, Hozumi T, Hattori S, Tagawa C, Kishimoto F, Björck $\mathrm{L}$. The gene sequence and some properties of protein $\mathrm{H}$. A novel IgG-binding protein. $J$ Immunol 1990; 144: 4046-4052.

14. Smirnov OYu, Denesyuk AI, Zakharov MV, Abramov VM, Zov'yalov VP. Protein V, a novel type-II IgG receptor from Streptococcus sp.: sequence, homologies and putative $\mathrm{Fc}$ binding site. Gene 1992; 120: 27-32.

15. Fahnestock SR, Alexander P, Nagle J, Filpula D. Gene for an immunoglobulin-binding protein from a group $\mathrm{G}$ streptococcus. $J$ Bacteriol 1986; 167: 870-880. 